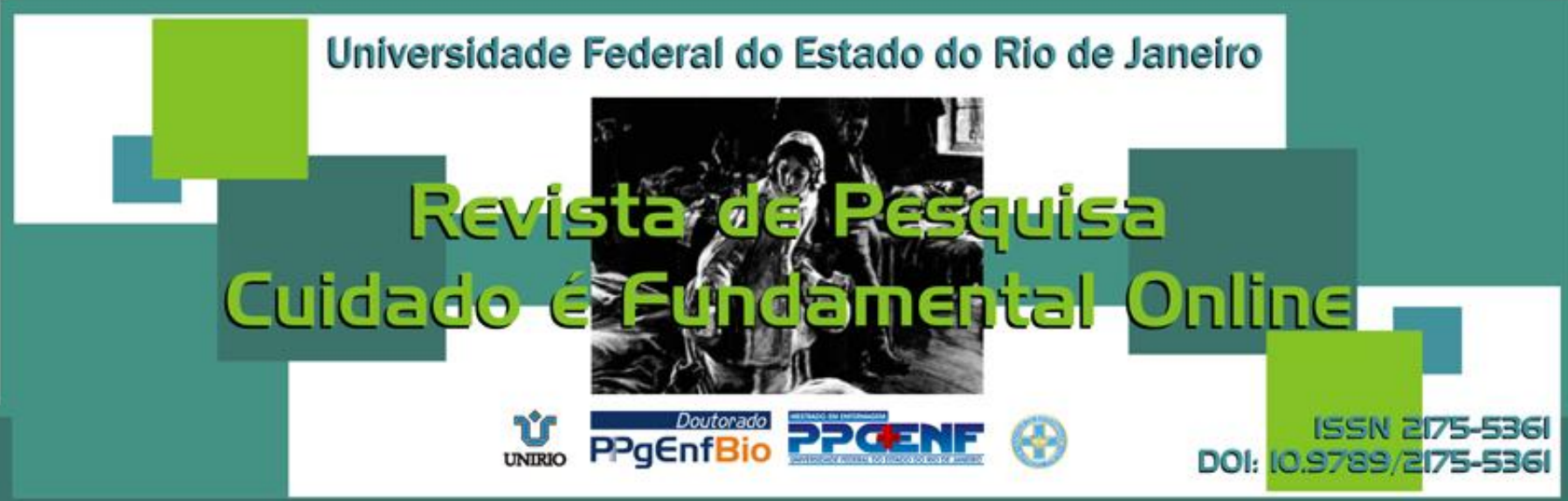

\title{
REVIEW
}

\section{The lipodistrofy in patients living with HIV / AIDS}

A lipodistrofia em pacientes que vivem com HIV/AIDS

El lipodistrofia en los pacientes que viven con el VIH / SIDA

Tiago Campos Armentano ${ }^{1}$, Alexandre Rosa da Silva ${ }^{2}$, Lorrana Vicente Ferrari ${ }^{3}$, Natalia Gonçalves Mateus ${ }^{4}$, Rosâne Mello ${ }^{5}$

ABSTRACT

Objective: To discuss the relationship between the presence of lipodystrophy in patients with HIV / AIDS and outline actions that optimize quality of life better. Method: This is a research type of qualitative literature. Data collection was conducted during the months of July and August 2011, through the database of the Electronic Library of Brazilian Scientific Journals (SciELO Brazil) and pubmed. We use the following keywords for search: HIV I AIDS and Lipodystrophy. Results: Based on reading the articles grouped the main changes related to lipodystrophy in three categories: 1) psychosocial changes, 2) bodily changes, and 3) metabolic disorders. Conclusion: Given the complexity of the effects caused by lipodystrophy, highlights the importance of multidisciplinary team with these clients and their families seeking comprehensive care and promote quality of life. Descriptors: Acquired immunodeficiency syndrome, Lipodystrophy, Nursing nutritional therapy, Physical Therapy.

\section{RESSUMO}

Objetivo: Discutir a relação entre a presença de lipodistrofia em pacientes portadores do vírus HIV/AIDS e esboçar ações que otimizem uma qualidade de vida melhor. Método: trata-se de uma pesquisa do tipo bibliográfica de natureza qualitativa. A coleta de dados foi realizada durante os meses de julho e agosto de 2011, através do banco de dados da Biblioteca Eletrônica de Periódicos Científicos Brasileiros (SciELO Brasil) e pubmed. Utilizamos os seguintes descritores para a busca: HIV/AIDS e Lipodistrofia. Resultados: Baseado na leitura dos artigos agrupamos as principais alterações relacionadas com a lipodistrofia em três categorias: 1) alterações psicossociais; 2) alterações corporais; e 3) alterações metabólicas. Conclusão: Tendo em vista a complexidade das repercussões ocasionadas pela lipodistrofia, destaca-se a importância do trabalho da equipe multiprofissional com essa clientela e seus familiares, buscando a integralidade da assistência e promoção da qualidade de vida. Descritores: Síndrome de imunodeficiência adquirida, Lipodistrofia, Enfermagem terapia nutricional, Fisioterapia.

$$
\text { RESIJMENM }
$$

Objetivo: Analizar la relación entre la presencia de lipodistrofia en pacientes con VIH / SIDA y las acciones de esquema que optimizan la calidad de vida mejor. MÉTODOS: Se trata de un tipo de literatura de investigación cualitativa. La recolección de datos se realizó durante los meses de julio y agosto de 2011, a través de la base de datos de la biblioteca electrónica de revistas científicas brasileñas (SciELO Brasil) y PubMed. Utilizamos las siguientes palabras clave para la búsqueda: VIH / SIDA y la lipodistrofia. Resultados: A partir de la lectura de los artículos agrupados los principales cambios relacionados con la lipodistrofia en tres categorías: 1) los cambios psicosociales, 2) los cambios corporales, y 3) trastornos metabólicos. Conclusión: Dada la complejidad de los efectos causados por la lipodistrofia, pone de relieve la importancia del equipo multidisciplinario con estos clientes y sus familias en busca de una atención integral y promover la calidad de vida. Descriptores: Síndrome de inmunodeficiencia adquirida, lipodistrofia, Terapia nutricional de enfermería, Terapia física.

${ }^{1}$ Graduated in Nutrition from UNISUAM, resident of the Program Multiprofessional in Health-UNIRIO. E-mail: tiagoarmentano@yahoo.com.br. ${ }^{2}$ Graduated in Physiotherapy by UNISUAM, resident of the Program Multiprofessional in Healt-UNIRIO. E-mail: alexandrelung@yahoo.com.br. ${ }^{3}$ Graduated in Nursing by UNIGRANRIO, resident of the Program Multiprofessional in Health-UNIRIO. E-mail: lorranaferrari@yahoo.com.br. ${ }^{4}$ Graduated in Nursing by UNIRIO, resident of the Program Multiprofessional in Health-UNIRIO. E-mail: nati_gonalves@yahoo.com.br. ${ }^{5} \mathrm{PhD}$ nurse in psychiatric nursing, associate professor of the Department of MedicalSurgical Nursing of the School Nursing Alfredo Pinto-UNIRIO. E-mail: rosane.dv@gmail.com. 


\section{INTRODUCTION}

The Acquired Immunodeficiency Syndrome (AIDS) is characterized by a severe dysfunction of the immune system of the individual infected with human immunodeficiency virus (HIV). Its clinical course is characterized by a considerable destruction of CD4 + T cells and can be divided into three stages: acute infection, asymptomatic infection, symptomatic disease.

Acute infection comes a few weeks after the initial infection and is difficult to diagnose because it resembles a common flu, or even a mononucleosis. In the second phase, the patient presents a picture of asymptomatic infection, which can last several years. The third phase, called symptomatic disease, the patient has several signs and symptoms such as prolonged fever, chronic diarrhea, weight loss, significant (greater than $10 \%$ of the previous weight of the individual), night sweats, fatigue and adenopathy. At this time, opportunistic infections begin to appear or reactivate such as tuberculosis, Pneumocystis carinii pneumonia, cerebral toxoplasmosis, candidiasis and cryptococci meningitis, among others. Rare tumors in immunocompetent individuals, such as Kaposi's sarcoma, non-Hodgkin lymphome can arise, characterizing AIDS.

The natural history of the disease has been extensively modified by antiretroviral therapy (ART). This slows the progression of infection to its final stage, increasing the length and quality of life of people with the disease. ${ }^{1}$ However, the reduction of morbidity and mortality from infectious diseases and neoplastic opportunists, have been watching the increasing prevalence of other diseases, including HIV-associated lipodystrophy. ${ }^{2}$

The lipodystrophy syndrome is a clinical condition characterized by several changes, including the body. Highlighting the peripheral lipoatrophy, such as loss of fat in the face, arms, legs and buttocks and lipohypertrophy manifested by dorsocervical fat accumulation, increased waist circumference and increased volume of the breasts. In lipodystrophy, there are metabolic disorders such as insulin resistance, dyslipidemia and altered glucose metabolism. ${ }^{3}$

It is believed that these changes are related to body use of anti-retroviral therapy, more specifically to the use of protease inhibitors. ${ }^{4}$

The complexity of lipodystrophy, which ranges from physical changes to the prejudice involved, suggests the approach to the patient under the eyes of many professionals. The multiprofessional teamwork is characterized by the reciprocal relationship between multiple intervention techniques and interaction among agents of different professional areas. ${ }^{5}$

Based on the above and in professional practice as residents entered into the Residency Program Multidisciplinary Health in a University Hospital located in Rio de Janeiro, the interest in addressing the issue. The group, composed of two nurses, a physiotherapist and a dietician, was faced with the complex reality faced by such patients during his time as residents with these clients. Being the clinic, the internal medicine ward, the ward clinical and surgical intensive care unit, parts of different scenarios experienced during our hospital practice. This paper aims to discuss the relationship between the presence of lipodystrophy in patients with HIV / AIDS and outline actions that optimize quality of life better. 


\section{METHODOLOGY}

This work it is a survey-type literature of qualitative nature. The qualitative approach in measuring variables is established to verify and explain their influence on others, based on the analysis of the frequency of incidents and statistical correlations. ${ }^{6}$

A literature search using an extensive literature study and analyze various aspects of a topic, favoring more structured future research. ${ }^{7}$

Data collection was conducted during the months of July and August 2011, through the database of the Electronic Library of Brazilian Scientific Journals (SciELO Brazil) and PubMed. We use the following keywords for search: HIV / AIDS and Lipodystrophy.

The selection of articles was performed by reading the title and summary of all those surveyed in the database. We excluded studies that reading the summary had no relation with the topic in question, along with experimental studies.

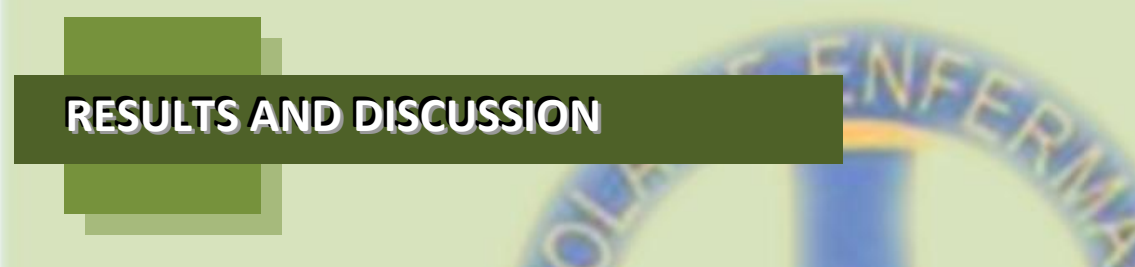

Based on reading the articles, we grouped the major changes related to lipodystrophy in three categories: 1) psychosocial changes, 2) bodily changes, and 3) metabolic abnormalities that can be seen in Table 1.

\begin{tabular}{lll}
\hline Bodily Changes & Metabolic Changes & \multicolumn{2}{l}{ Psychosocial Changes } \\
\hline $\begin{array}{l}\text { Central } \\
\text { Lipohypertrophy }\end{array}$ & Hypertriglyceridemia & $\begin{array}{l}\text { Difficulties in social } \\
\text { relations }\end{array}$ \\
$\begin{array}{lll}\text { Peripheral Lipoatrophy } \\
\text { Hypercholesterolemia }\end{array}$ & $\begin{array}{l}\text { Difficulties in sexual } \\
\text { relations }\end{array}$ \\
Mixed Lipodystrophy & Mixed Dyslipidemia & Loss of self-esteem \\
& Insulin resistance and / & Social isolation \\
& or diabetes mellitus type & \\
\hline
\end{tabular}

Table 1 - Major Changes observed in Lipodystrophy

\section{Psychosocial alterations}

With the bodily changes that cause the lipodystrophy syndrome in patients with HIV / AIDS on antiretroviral therapy, there may be psychological and emotional difficulties these people. We can visualize these difficulties in an article where the patients interviewed reported having difficulties in social relationships, such as social avoidance, difficulty in sexual relations due to not feel more sexually attractive, loss of self-image and reduced self-esteem, depression, and fear consequent forced disclosure of the diagnosis, the possible association of symptoms with the disease. However, the paper shows through its results, which family relationships and work are relatively not affected, and the family in general source of social support. In relation to work, approximately half of the 21 participants were retired and did not use this modality as social networking. 
Those who worked reported that the fact of having the disease was unknown by his colleagues, who in turn reported the presence of signs of lipodystrophy generated embarrassment at work. This same study found that in general social relationships were unaffected by the presence of lipodystrophy. However, five participants reduced social contacts, complained of introversion and greater avoidance of occasions that involved meeting with people who knew them before the onset of lipodystrophy changes that entails. Also noteworthy is that most relationships are negatively affected loving in general for those without a steady partner. ${ }^{8}$

Regarding the identification of lipodystrophy, most respondents reported that the first signs of the disease were weight loss of face. Regarding lipohypertrophy 16 people are reported to fat gain in the abdominal region. ${ }^{8}$

It is also noteworthy that live with HIV / AIDS implies changes in behavior, lifestyle, habits, social and emotional impacts, constant use of medications, hospital visits applicants, besides the permanent coexistence with the impossibility of healing. ${ }^{9}$

Adopting strategies as cosmetic procedures and plastic surgery, were identified as mitigating the consequences of lipodystrophy in relation to psychological well-being of these patients. Based on the above, Brazil has been a pioneer in offering free reconstructive surgeries for patients living with HIV / AIDS and use of antiretrovirals. This right, guaranteed by decree 2582 / GM December 2004, includes 8 table repair surgeries in the hospital information system SUS: a hump liposuction, liposuction of the abdominal wall, breast reduction, treatment of gynecomastia, fat grafting for buttock reconstruction gluteal fat tissue with tissue fillers, facial filling with polymethylmethacrylate (PMMA). ${ }^{10}$

The article emphasizes that resort to plastic surgery, as well as being a way to reduce physical and aesthetic changes, helps in improving the psychological and social aspects involved, by removing signs that depict a stigmatizing disease, collaborating with well-being. ${ }^{9}$

\section{Body changes}

Based on the articles analyzed the bodily changes are frequently reported by patients themselves and later confirmed by clinical examination. The most common changes are the central lipohypertrophy (abdominal fat accumulation and / or trunk, breasts, dorsocervical region or also called buffalo-hump), peripheral lipoatrophy (fat atrophy ball of bichart, prominence of veins in the arm and leg) or mixed lipodystrophy (which include both changes). ${ }^{3,11}$

In a study that looked at the prevalence of lipodystrophy in 180 Brazilian adults, $57 \%$ of subjects reported some body alteration. A percentage of $43 \%$ of women noted more frequently in central lipohypertrophy, followed by mixed lipodystrophy in $40 \%$ of women. A percentage of $34 \%$ of men reported peripheral lipoatrophy, followed by mixed lipodystrophy in $34 \%$ of men and central lipohypertrophy in $32 \%$ of men. ${ }^{3}$

In 2006, a study was conducted with 223 adults of both sexes in use of antiretroviral therapy (HAART) with protease inhibitor (PI) for at least three years. The aim of the study was to evaluate the association between dietary intake and the presence of abdominal obesity, defined by the ratio of waist and hip circumferences, as follows:> 0.95 for men and> 0.85 for women. The prevalence of abdominal obesity in the group was $45.7 \%$ and was associated with greater consumption of fat. ${ }^{3}$

In a prospective cohort study conducted in Canada, from October 1998 to May 2001, with 366 patients who started the first time the use of antiretroviral therapy, the presence of morphological changes and lipid was observed. There was an incidence of $29 \%$ for lipoatrophy, lipohypertrophy and $23 \%$ to $13 \%$ for mixed lipodystrophy. ${ }^{11}$ 


\section{Metabolic abnormalities}

In lipodystrophy, there are metabolic disorders such as insulin resistance, dyslipidemia and altered glucose metabolism. ${ }^{12}$

A study performed in 176 patients with Minas Gerais, where $76 \%$ of users (ART) and $24 \%$ nonusers, sought to evaluate the use of ART and lipid and glycemic these patients. This study showed that HAART users had levels of triglycerides, total cholesterol and lipid fractions (HDL-cholesterol, LDL-cholesterol, VLDL-cholesterol) were significantly higher. Regarding fasting glucose values were not significant when the two groups were compared. But statistical significance when administered $75 \mathrm{~g}$ of dextrose and glucose levels checked after 60 and 120 minutes.

Another cross-sectional study aimed to assess the presence of lipodystrophy and its relationship with lipid profile and insulin resistance in thirty Brazilian children and adolescents on antiretroviral therapy with a median of 28.4 months at the time of the study. However, there were no statistically significant differences in any of the evaluated parameters (HOMA-IR, triglycerides, HDLcholesterol and LDL-cholesterol). ${ }^{12}$

Based on the changes described above suggest different actions aiming at improving the quality of life of these patients.

\section{Nursing actions}

Nursing assignments have to be worked both individually and collectively. Patients living with HIV / AIDS are more susceptible to opportunistic infections, underscoring the need for infection control measures, including the use of personal protective equipment by professionals. Such measures are general and should be applied in all patients. How to care more targeted to this audience we can cite the formulation of strategies by the multidisciplinary team for the realization of comprehensive care, the incentive for individuals to formulate a plan of life, encouraging the patient living with HIV / AIDS to take a stance front their lives and overcome the obstacles imposed by discrimination and prejudice, identification with the patient of their own potential and resources available in the community to meet their needs and information about their rights. Such care is facilitated by nursing staff contact with these patients over time. Thus favoring the creation of links, confidence and making it possible therapeutic communication.

Regarding the identification with the patient about the resources available in the community, we can cite, for example, the existence of support groups. Such groups allow contact with other individuals facing similar problems. This is the space in which the individual verbalizes their fears, anxieties, worries and difficulties of everyday life.

The patient may also be informed about the Ordinance 2582/2004.

Besides the concern for the patient, is crucial concern for their families. An illness in the family inserted can cause significant changes in household living, which may cause the risk of not adapting. Any family that demonstrates a difficulty in dealing with AIDS may need outside help and additional resources. ${ }^{14}$

Nurses should stick to the complex family problem. This network of relationships requires an understanding that takes into account their integration in the socio-economic and cycle time lived. ${ }^{15}$

The professional must be able to observe and recognize the role of the family to answer the health of their members, should consider the questions, opinions and actions of the family in proposing his actions. A family assistance entails knowing how each family cares and identifies difficulties and coordinates their efforts. Professionals should use their knowledge about each family and in 
conjunction with each of them think and implement the best possivel15 assistance based on information obtained.

\section{Shares of physiotherapy}

Besides the change in body fat distribution and metabolic changes, several other changes may occur in HIV-infected patients who use therapy (ART). Among them we can find orthopedic changes, the most common osteoporosis, osteopenia, carpal tunnel syndrome and adhesive capsulitis. ${ }^{16}$

Osteoporosis and osteopenia are influenced multifactorial as activation of proinflammatory cytokines, direct action of the virus on bone cells, alterations in vitamin D metabolism and use of antiretroviral therapy, especially protease inhibitors. Knowing that the principal measure for preventing osteoporosis is the regular practice of physical activity and that HIV-infected patients who have lipodystrophy have a tendency to social isolation, is very important to promote regular physical activity individually or in groups, in order to prevent possible changes orthopedic and promote greater social interaction. ${ }^{16}$

In this sense therapy comprises a primary support nutrition, it is necessary higher intake of calcium and even administration of vitamin $D$ supplementation.

According to a systematic review published in 2008, the group exercise programs promote greater socialization of these patients, an important instrument of social engagement and professional. Besides serving as a strategy for reducing cardiovascular risk in HIV-infected patients who present change in body fat distribution, also contributing to the increase in insulin sensitivity. The author describes the importance of performing a multidisciplinary approach for the treatment of these patients in order to promote a better quality of life. ${ }^{17}$

\section{Shares of nutrition}

From a nutritional standpoint, few articles related to the management of patients with lipodystrophy are found in the literature. However, in clinical practice we observed that this population often develops metabolic syndrome (MS). A complex and multifactorial disorder that is associated with increased cardiometabolic diseases. ${ }^{18}$

According to the American Heart Association and the National Heart, Lung, and Blood Institute (AHA/NHLBI- 2005) the diagnosis of MS is determined by the presence of three or more of the following conditions: abdominal obesity (measured by waist circumference values exceeding $102 \mathrm{~cm}$ and $88 \mathrm{~cm}$ in men and women, respectively), hypertension (defined as blood pressure equal to or greater than $130 / 85 \mathrm{mmHg}$ ), impaired glucose tolerance or diabetes mellitus (fasting glucose greater than or equal to $100 \mathrm{mg} \mathrm{/} \mathrm{dl)} \mathrm{,} \mathrm{hypertriglyceridemia} \mathrm{(values} \mathrm{equal} \mathrm{to} \mathrm{or} \mathrm{above} 150 \mathrm{mg} / \mathrm{dl}$ ) and low blood concentrations of HDL-C (less than $40 \mathrm{mg} / \mathrm{dl}$ for men and $50 \mathrm{mg} / \mathrm{dl}$ for women). ${ }^{19}$

\section{Recommendations macronutrients}

The recommendation of carbohydrates should be between 50 to $60 \%$ of the total caloric value (TCV), which prioritized the complex, such as whole grains, fruits and vegetables. ${ }^{20}$

The fibers are complex carbohydrates that are classified according to their solubility. Soluble fibers are represented by pectin (fruit) and the gums (oats, barley and legumes) and are related to reduced gastrointestinal transit and control of dyslipidemia. Regarding the insoluble fibers, they do not act on the cholesterol, but increase satiety and accelerate gastrointestinal transit. Represented by cellulose (wheat), hemicellulose (grains) and lignin (vegetables). The daily recommendation of fiber 
for adults is 20 to $30 \mathrm{~g}$, and 5 to $10 \mathrm{~g}$ soluble fiber, as an additional measure for reduction of cholesterol. $^{20}$

It is recommended protein intake of 0.8 to $1.0 \mathrm{~g} / \mathrm{kg}$ current or $15 \%$ of total caloric value. Although hyperprotein diets and low-carbohydrate concentrations can promote weight loss and improve glucose in the short term, its effectiveness is not well established long term. ${ }^{21}$

Regarding the ingestion of lipids, their intake should range between 25 and 35\% of the VCT, with less than $7 \%$ saturated fat, $10 \%$ and $20 \%$ polyunsaturated and monounsaturated up to $200 \mathrm{mg} / \mathrm{day}$ of cholesterol. ${ }^{22}$

The omega- 3 is associated with decreased triglyceride levels, decreased platelet aggregation and blood pressure while minimizing the risk of $\mathrm{CHD}$ and increasing insulin sensitivity. ${ }^{20}$

\section{Additional recommendations}

The consumption of sodium chloride should be limited to $6 \mathrm{~g} /$ day or $2400 \mathrm{mg}$ of sodium and 100 meq / day of sodium. Should be avoided processed foods like sausages, canned, smoked and canned. Natural seasonings like parsley, chives and herbs are recommended instead of industrialized condiments. $^{21}$

Excessive consumption of alcohol raises blood pressure and can also cause a resistance antihypertensive therapy. In general, the use of alcoholic beverages must be inadvisable to hypertensive subjects, hypercholesterolemia and aimed at weight loss, since each gram of alcohol is $7.0 \mathrm{kcal}$. In the case of those who choose to consume alcohol, it is advisable that consumption does not exceed $30 \mathrm{ml}$ of ethanol / day. This corresponds to $60 \mathrm{ml}$ of liquor, wine of $240 \mathrm{ml}$ or $720 \mathrm{ml}$ beer. For women, the dosage should not be above $15 \mathrm{~g}$ ethanol / day. ${ }^{23}$

Given the changes in lipid profile and high prevalence of overweight and obesity in individuals with metabolic syndrome, there is a need for supplementation of antioxidant nutrients to combat oxidative stress. These include vitamins A, C and E, copper, selenium and zinc. Planning is needed nutrition education associated with these measures, aiming to control the syndrome and preventing the rise of co-morbidities. ${ }^{24}$

The adoption of model DASH diet (Dietary Approaches to Stop Hypertension) Diet and the Mediterranean which recommend the use of vegetables, legumes, whole grains, fruits, dairy products low in total fat, saturated fat, cholesterol and trans, high amount of monounsaturated fat (olive oil) and omega- 3 and provide high amounts of potassium, magnesium and calcium may be a therapeutic option in metabolic syndrome when associated with a lifestyle intervention. ${ }^{25}$

Weight loss is more effective when regular exercises are daily. The basic recommendations include aerobic exercise, lasting 30 to 60 minutes per day. Besides helping in losing weight, regular physical activity is associated with improved insulin resistance, reduction in blood pressure levels and increased HDL-cholesterol. The goal of treatment is a weight loss of about $7 \%$ to $10 \%$ of body weight in a period of 6 to 12 months. The recommended speed for slimming should be $2-4 \mathrm{~kg}$ per month. ${ }^{26}$

\section{CONCLUSION}

Given the complexity of the effects caused by lipodystrophy, especially coping with the physical and emotional suffering, which ultimately lead to social isolation, highlights the importance of multidisciplinary team with these clients and their families seeking comprehensive care and enhancing the quality of life. 
Due to the lack of national studies that address this issue, we emphasize the importance of further studies in the area, especially studies that address the role of the multidisciplinary team in the care of these patients.

\section{REFERENCES}

1. Brasil, Ministério da Saúde. Secretaria de Vigilância em Saúde, Departamento de Vigilância Epidemiológica. Doenças infecciosas e parasitárias: guia de bolso- 4. ed. ampl.- Brasília: 2004.

2. Hadigan C, Meigs JB, Corcoran C, Rietschel P, Piecuch S, Basgoz N, et al. Metabolic abnormalities and cardiovascular disease risk factors in adults with human immunodeficiency virus infection and lipodystrophy. Clin Infect Dis. 2001;32:130-9.

3. Diehl LA, Dias JR, Paes ACS, Thomazini MC, Garcia LR, Cinagawa E, et al. Prevalência da Lipodistrofia Associada ao HIV em Pacientes Ambulatoriais Brasileiros: Relação com Síndrome Metabólica e Fatores de Risco Cardiovascular. Arq Bras Endrocrinol Metab. 2008;52/4.

4. Sociedade Brasileira de Infectologia. Terapia Anti-retroviral e Alterações Metabólicas. Ano I, n¹, out/nov/dez 2005.

5. Peduzzi M. Trabalho em equipe multiprofissional. Rev Saúde Pública 2001;35(1):103-9.

6. Chizzotti A. Pesquisa em ciências humanas e sociais. São Paulo: Cortez; 2000.

7. Dyniewicz AM. Metodologia da pesquisa em saúde para iniciantes. São Paulo: Difusão; 2009.

8. Seidl EMF, Machado ACA. Bem estar psicológico, enfrentamento e lipodistrofia em pessoas vivendo com HIV/AIDS. Psicologia em Estudo, Maringá, v. 13 n. 2, p. 239-247,abr./jun. 2008

9. Alencar Tatianna Meireles Dantas de, Nemes Maria Ines Battistella, Velloso Marco Aurélio. Transformações da "aids aguda" para a "aids crônica": percepção corporal e intervenções cirúrgicas entre pessoas vivendo com HIV e aids. Ciênc. saúde coletiva. 2008 Dec; 13(6): 1841-1849.

10. Brasil, Ministério da Saúde. PORTARIA No 2.582/GM de 02 de dezembro de 2004, que inclui nas tabelas de procedimentos do SUS as cirurgias reparadoras para pacientes portadores de HIV/Aids e para usuários com acesso à antiretrovirais e define os mecanismos para operacionalização desses procedimentos nos Sistemas de Informações - SIA e SIH/SUS.

11. Jaime PC, Florindo AA, Latorre MRDO, Segurado AAC. Central Obesity and dietary intake in HIV/AIDS patients. Rev Saúde Pública 2006;40(4):634-40.

12. Heath KV, Chan KJ, Singer J, O'Shaughnessy MV, Montaner JSG, Hogg RS. Incidence of morphological and lipid abnormalitties: gender and treatment diffentials afte initiation of first antiretroviral therapy. International Journal of Epidemiology 2002; 31:1016-1020.

13. Sarni ROS, Souza FIS, Battistini TRB, Pitta TS, Fernandes AP, Tardini PC, et al. Lipodistrofia em crianças e adolescentes com síndrome da imunodeficiência adquirida e sua relação com a terapia antirretroviral empregada. Jornal de Pediatria 2009; 85(4).

14. Lima ALM et al. Perguntas e respostas HIV/AIDS. São Paulo: Atheneu, 1996.

15. Senna MD, Antunes EH. Abordagem da Família (a Criança, o Adolescente, o Adulto e o Idoso no Contexto da Família), 2001.

16. Lima ALLM, Godoy AL, Oliveira PRD, Gobbi RG, Silva CA, Martino PB, et al. Alterações Ortopédicas na AIDS. Rev Bras Ortop.2009; 44(3):186-90. 
17. Quezia AT, Cavalcanti N; Costa IS, Bernardes KO. Fisioterapia no contexto do HIV/AIDS. Fisioter. Mov. 2008; 21(4):11-18.

18. Rossi M, Neto AS, Rossi FMB, Amarante RDM, Alcântara GC, Silva RBF, et al. Percentage of excess BMI lost correlates better with improvement of metabolic syndrome after Roux-en- $Y$ gastric bypass in morbidly obese subjects: anthropometric indexes and gastric bypass. Surg Obes Relat Dis. 2009; 5: 918.

19. Grundy S M, Cleemen JI, Daniels SR, Donato KA, Eckel RH,Franklin BA, et al. Diagnosis and management of the metabolic syndrome: an American Heart Association/ National Heart, Lung, and Blood Institute Scientific Statement Circulation. 2005; 112 (17): 2735- 2752.

20. Rodrigues CSC, Reis NT. Síndrome metabólica. In: Jaqueline FF. Nutrição e doenças cardiovasculares. $1^{\circ} \mathrm{ed}$. São Paulo: Atheneu, 2005.

21. Bressan J, Coelho SB. Abordagem nutricional na síndrome metabólica. Revista Nutrição em Pauta, São Paulo, p.10-15, 2008.

22. National Cholesterol Education Program (NCEP). Expert Panel on Detectation, Evaluation, and Treatment of High Blood Cholesterol in Adults (Adult Treatment Panel III). Final Report, 2002.

23. Costa RP, Silva CC, Pimentel IC. Terapia nutricional nas doenças cardiovasculares. In: CHEMIM, S. M.; MURA, J. D. P. Tratado de alimentação, nutrição e dietoterapia. $1^{\circ}$ ed. São Paulo: Roca, 2007.

24. Fernandes M, Paes C, Nogueira C, Souza G, Aquino L, Borges, F, et al. Perfil de consumo de nutrientes antioxidantes em pacientes com síndrome metabólica. Revista de Ciências Médicas; 2007. 16: 209-219.

25. Sociedade Brasileira de Cardiologia. I Diretriz brasileira de diagnóstico e tratamento da síndrome metabólica. Arquivos Brasileiro de Cardiologia, v. 84 (suplemento: 1), p. 1-28, 2005.

26. Wesley SRA, Suplicy H. Como diagnosticar e tratar síndrome metabólica.2009; Revista Brasileira de Medicina. 2008; 36-45.

Received on: 01/11/2011

Required for review: no

Approved on: 21/03/2013

Pubished on: 01/12/2013
Corresponding Address: Praça 13 de Junho 133 Cordovil, Rio de Janeiro/ RJ; Brasil. Tel.: (21) 7871-0887. Email: tiagearmentano@yahoo.combr 